\title{
Pulsed Electrodeposition of Thin Cobalt Coating Layer on Femitic Stainless Steel for SOFC Interconnects
}

\author{
Suk-Chul Kwak ${ }^{1, \dagger}$, Byung Kyu Kim ${ }^{1,2}$, Dong-Ik Kim ${ }^{1}$, and Young Whan Cho ${ }^{1, *}$ \\ ${ }^{1}$ High Temperature Energy Materials Research Center, Korea Institute of Science and Technology, Seoul 02792, \\ Republic of Korea \\ ${ }^{2}$ Department of Materials Science and Engineering, Seoul National University, Seoul 08826, Republic of Korea \\ 'ILJIN Steel Corporation, Imsil 55927, Republic of Korea
}

\begin{abstract}
A thin, compact, and uniform cobalt layer was coated on ferritic stainless steel (Crofer 22 APU) by high frequency square pulsed electrodeposition in an aqueous solution containing cobalt chloride and boric acid. The effects of various electrodeposition parameters and post heat treatment on the morphology, thickness, roughness and adhesion of the coating layer were investigated. It was found that neutralizing with sodium hydroxide solution after acid washing of the polished sample surface prevented delamination of the sub-surface layer. The addition of boric acid had a strong influence on the nucleation and agglomeration behavior of the deposited $\mathrm{Co}$, which consequently controlled both the thickness and the roughness of the coating layer. With increasing current density, the grain size decreased and, therefore, a more uniform microstructure could be achieved. The duty cycle of the square pulse strongly affected the morphology but not the roughness of the coating layer. Subsequent heat treatment at $800{ }^{\circ} \mathrm{C}$ in air greatly improved the adhesion of the Co layer to the substrate. By optimizing the aforementioned electrodeposition parameters and adopting the post heat treatment, it was possible to obtain a fine, uniform, compact, and thin $(<2 \mu \mathrm{m})$ Co layer with excellent adhesion properties.
\end{abstract}

(Received April 19, 2017; Accepted June 17, 2017)

Keywords: electrodeposition, Co coating, ferritic stainless steel, SOFC, interconnect

\section{INTRODUCTION}

Fuel cells are devices that directly convert chemical energy to electrical energy by electrochemical processes. The solid oxide fuel cell (SOFC) has the advantages of flexible fuel selection and high efficiency, and has no need of fuel reformers, which allows it to be developed as a combined cycle system. Nonetheless, its high operating temperature, greater than $700{ }^{\circ} \mathrm{C}$, has delayed SOFC commercialization, because the temperature limits the selection of materials suitable for stack components, and introduces unresolved issues with long-term stability and stack sealing [1].

The SOFC interconnect is one of the main SOFC components. The two main roles of the interconnect are to act as the physical barrier and electrical connector between cells, and so the essential technical requirements for the interconnect material are strong oxidation resistance and high

* Corresponding Author: Young Whan Cho [Tel: +82-2-958-5465, E-mail: oze@kist.re.kr]

Copyright (c) The Korean Institute of Metals and Materials electrical conductivity. In the early stage of SOFC development, given the high operating temperatures $(\sim 1000$ ${ }^{\circ} \mathrm{C}$ ) of the SOFC systems, the only materials that could be used for interconnects were ceramic materials. However, following the introduction of an electrode-support type SOFC whose operation temperature was reduced to the range of 600 to $800{ }^{\circ} \mathrm{C}$, the use of metallic interconnects have drawn increasing attention $[1,2]$. Based on their high thermal and electrical conductivity, good machinability, and cost-effectiveness, Fe-base metallic interconnects have been considered a viable choice $[3,4]$.

The Fe-base materials used in to SOFC interconnects are chromia forming ferritic stainless steel with a $\mathrm{Cr}$ content greater than $16 \mathrm{wt} \%$. Such alloys possess a coefficient of thermal expansion coefficient (CTE) matching those of the other SOFC components. However, one of the drawbacks of the chromia forming alloys is the inevitable production of gaseous $\mathrm{Cr}^{6+}$ containing species through reactions with oxidants $\left(\mathrm{O}_{2}\right.$ and $\left.\mathrm{H}_{2} \mathrm{O}\right)$, particularly at the cathodic side [5]. It 
Table 1. Chemical composition (wt $\%$ ) of Crofer 22 APU.

\begin{tabular}{lccccccccccc}
\hline & $\mathrm{Cr}$ & $\mathrm{Fe}$ & $\mathrm{C}$ & $\mathrm{Mn}$ & $\mathrm{Si}$ & $\mathrm{Cu}$ & $\mathrm{Al}$ & $\mathrm{S}$ & $\mathrm{P}$ & $\mathrm{Ti}$ & $\mathrm{La}$ \\
\hline Min. & 20 & Bal. & & 0.3 & & & & & & 0.03 & 0.04 \\
Max. & 24 & Bal. & 0.03 & 0.8 & 0.5 & 0.5 & 0.5 & 0.02 & 0.05 & 0.2 & 0.2 \\
\hline
\end{tabular}

has been reported that the $\mathrm{Cr}^{6+}$ containing species are reduced to a $\mathrm{Cr}_{2} \mathrm{O}_{3}$ precipitate at the triple phase boundary (gas phase - electrolyte - cathode), eventually leading to polarization loss, and so-called "Cr poisoning" [3,5-7].

To address the "Cr poisoning" issue while still retaining or improving both oxidation and electrical properties, surface modification of the metallic interconnects using various coating materials has been attempted [8-12]. For instance, direct deposition of protective coatings made of perovskite (La, Sr) $\mathrm{MnO}_{3}$ [13-15] or spinel (Mn, Co) $)_{3} \mathrm{O}_{4}$ [16-18] have had a beneficial impact on oxidation resistance and electrical conductivity. In addition to ionic materials, the deposition of spinel-forming transition metals has also been reported to be very effective. According to Deng et al., Co-electroplated UNS430 exhibited a lower area specific resistance than an uncoated sample after oxidation for 1900 h [19]. Stanislowski et al. showed that $\mathrm{Co}, \mathrm{Ni}$, and $\mathrm{Cu}$ deposited by magnetron sputtering were transformed into stable protective oxide layers, effectively suppressing $\mathrm{Cr}$ evaporation by two orders of magnitude [20,21].

The interconnect employed in planar SOFCs has a complex geometry because of the channels in the structure used for injecting fuel gas and air [22]. Among various coating methods, pulse electroplating was employed for deposition because of its ability to coat a complex-shaped interconnect $[22,23]$. Co was selected as the coating material because it is converted into Co spinel oxides which have moderate electrical conductivity and thermal stability due to their good CTE match [8,24,25].

In the present study, a compact, fine, uniform, and extremely thin Co layer was coated on ferritic stainless steel (Crofer22 APU) by pulsed electrodeposition in a cobalt chloride aqueous solution containing boric acid at room temperature. The effects of various coating parameters including surface cleaning process, pulse duration and frequency, and current density, on the morphology and
Table 2. The composition, temperature, and $\mathrm{pH}$ of the coating solutions.

\begin{tabular}{lccccc}
\hline & $\mathrm{CoCl}_{2} \cdot 6 \mathrm{H}_{2} \mathrm{O}$ & $\mathrm{H}_{3} \mathrm{BO}_{3}$ distilled & $\mathrm{pH}$ & Temperature \\
& & \multicolumn{2}{c}{ water } & $\mathrm{g}$ & \\
\hline Process A & $100 \mathrm{~g}$ & $60 \mathrm{~g}$ & $1000 \mathrm{ml}$ & $2.5 \sim 3$ & $50{ }^{\circ} \mathrm{C}$ \\
Process B & $100 \mathrm{~g}$ & $35 \mathrm{~g}$ & $1000 \mathrm{ml}$ & $3 \sim 3.5$ & $25{ }^{\circ} \mathrm{C}$ \\
\hline
\end{tabular}

uniformity of the coating layer were investigated. The effects of post heat treatment on coating adhesion, as well as the evolution of the oxide phase after heat treatment, were also studied.

\section{EXPERIMENTAL}

Commercial high $\mathrm{Cr}$ steel (Crofer22 APU, Thyssen Krupp), one of the metallic interconnect materials commonly used for intermediate temperature SOFC devices, was adopted in the present work. The chemical composition of the alloy is given in Table 1. As-received $2 \mathrm{~mm}$ thick sheet was cut into $18 \mathrm{~mm}$ x $18 \mathrm{~mm}$ squares and both surfaces were polished using $\mathrm{SiC}$ papers up to 2000-grit. A stainless steel wire of $0.5 \mathrm{~mm}$ in diameter was then spot welded to one side of the square sample to apply the pulsed current. A surface cleaning treatment was applied afterward. The sample was cleaned using a $10 \mathrm{vol} \% \mathrm{NaOH}$ aqueous solution and then by acetone for $30 \mathrm{~min}$ each in an ultrasonic bath, followed by washing with distilled water to remove the remaining chemicals on the surface. It was then immersed into a 10 vol\% $\mathrm{HCl}$ aqueous solution for between 1 and $3 \mathrm{~min}$ to create a rough surface with sub-micron scale. After washing with ethanol, the sample was finally immersed into the $10 \mathrm{vol} \%$ $\mathrm{NaOH}$ solution again for $1 \mathrm{~min}$ to prevent the delamination of the sub-surface layer of the substrate after electrodeposition.

The coating solution was prepared by dissolving cobalt chloride hexahydrate $\mathrm{CoCl}_{2} \cdot 6 \mathrm{H}_{2} \mathrm{O}(>98.5 \%)$ and boric acid $\mathrm{H}_{3} \mathrm{BO}_{3}(>95 \%)$ in distilled water. The composition, $\mathrm{pH}$, and temperature of the coating solutions are given in Table 2. A programmable DC power supplier was used to control current density, square pulse duration, and frequency. The anode was made with two Pt-plated Ti meshes of $100 \mathrm{~mm}$ width and 120 $\mathrm{mm}$ height, and placed in an electroplating bath. The polished and cleaned cathode sample was then positioned in the middle 


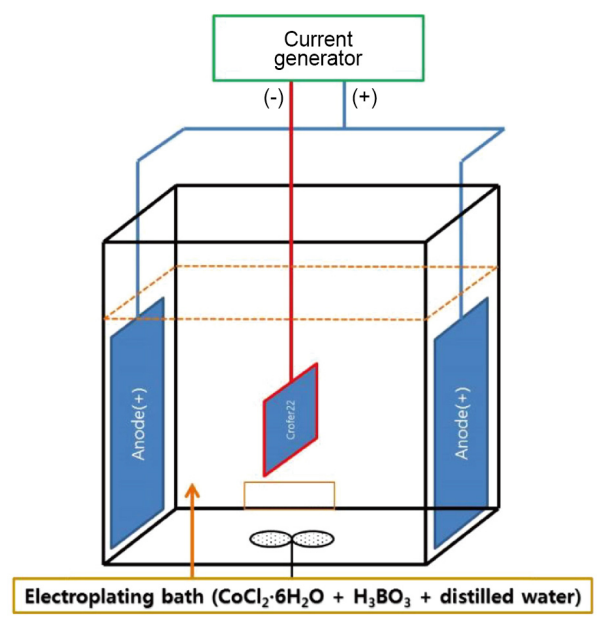

Fig. 1. A schematic drawing of the pulsed electroplating apparatus.

of the anode as shown in Fig. 1. The distance between the two anodes was $105 \mathrm{~mm}$, and the stainless steel lead wire was insulated with PTFE tape. The coating solution was stirred at 45 strokes per min by two linear stirring plates made of PMM placed between the anode and cathode to promote uniform coating. Among known pulsed electrodeposition modes such as square pulse, periodic reverse, and asymmetric sine, the square pulse wave with the constant current mode was chosen in this study. The frequency and the duty cycle were changed from 10 to $100 \mathrm{~Hz}$ and from 20 to $80 \%$, respectively. The current density was varied from 64 to $400 \mathrm{~mA} / \mathrm{cm}^{2}$ and the total coating time was varied between 28 and $175 \mathrm{sec}$. After the electrodeposition process was finished, the coated sample was thoroughly washed with water, immediately followed by drying by compressed air and a hot air drier.

The morphology of the surface and its intersection with the coating layer were examined by field emission gun scanning electron microscopy (Inspect F50, FEI) equipped with energy dispersive X-ray spectroscope (EDS). The roughness of the coating layer was evaluated using a $3 \mathrm{D}$ image reconstruction program (Mex 5.1, Alicona). Its 3D structure was reconstructed by combining a set of images acquired from $0^{\circ}$, $5^{\circ}$, and $10^{\circ}$-tilted positions. The resolution of roughness measurements depends on the magnification of the acquired image. In this study, images at a magnification of $50,000 \mathrm{x}$ were used to guarantee the accuracy of the nanoscale roughness investigation.
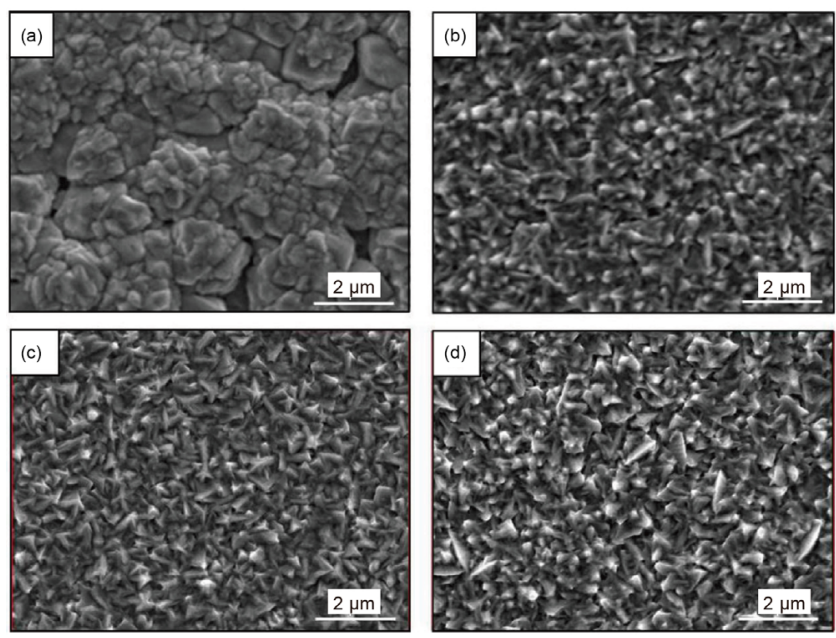

Fig. 2. Influence of boric acid and solution temperature on morphology of coating layer a) without boric acid at $25{ }^{\circ} \mathrm{C}$, b) and c) $35 \mathrm{~g}$ boric acid in $1000 \mathrm{ml}$ distilled water at $25{ }^{\circ} \mathrm{C}$, and d) $60 \mathrm{~g}$ boric acid in $1000 \mathrm{ml}$ distilled water at $50{ }^{\circ} \mathrm{C}$. Current density = $160 \mathrm{~mA} / \mathrm{cm}^{2}$, frequency $=100 \mathrm{~Hz}$, duty cycle $=50 \%$, total coating time $=70 \mathrm{~s}$.

The composition of the crystalline phase of the coating layer was analyzed before and after heat treatment at $800{ }^{\circ} \mathrm{C}$ in air, using a Bruker D8 ADVANCE XRD equipped with a $\mathrm{Cu}$ target and LynxEye 1D-Detector. The adhesion strength of the coating layer was evaluated by a scratch tester (Scratch Tester PRO, J\&L Tech). The test length and speed were 4 $\mathrm{mm}$ and $0.1 \mathrm{~mm} / \mathrm{sec}$, respectively. The load was varied from 0 up to $20 \mathrm{~N}$ continuously in order to compare the adhesion strength of the varios square pulse electrodeposited coating layers, before and after the high temperature heat treatment in air.

\section{RESULTS AND DISCUSSION}

\subsection{Effect of boric acid}

Cobalt can be electroplated in all sulfate, chloride, sulfate-chloride, mixed solution, sulfamate, ammonium sulfate, and fluoborate solutions [26]. It is also known that the $\mathrm{pH}$ and temperature of the solution will affect the mechanical properties of the electrodeposited Co layer [27]. In the present study, a Cobalt chloride solution with boric acid was used and the $\mathrm{pH}$ was maintained between 3 and 3.5. The concentration of boric acid commonly used for Cobalt coating with a chloride solution is $60 \mathrm{~g}$ in $1000 \mathrm{ml}$ distilled water, and the 

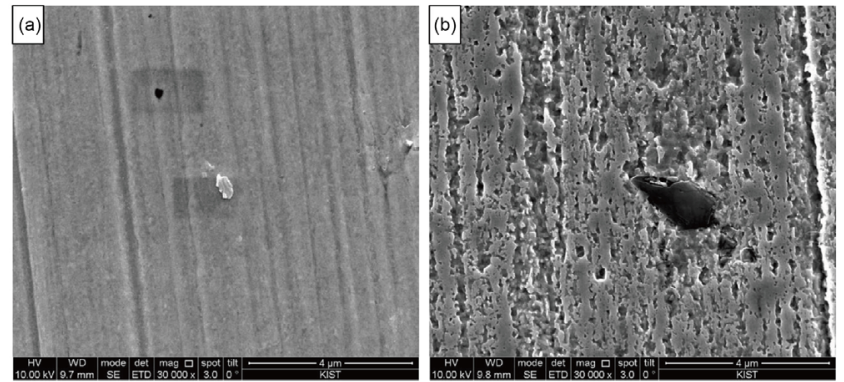

Fig. 3. Influence of acid washing on surface morphology of substrate before coating a) before acid washing and b) after acid washing for $3 \mathrm{~min}$ in $10 \mathrm{vol} \% \mathrm{HCl}$ solution.

solution temperature is maintained above $50{ }^{\circ} \mathrm{C}$ [26] to ensure the complete dissolution of the boric acid. When this coating condition (Process A, Table 2) was used in the present study, however, it was difficult to obtain a uniform and compact coating layer thinner than $3 \sim 5 \mu \mathrm{m}$. After several preliminary tests with different levels of boric acid and solution temperature, it was found that $35 \mathrm{~g}$ boric acid in $1000 \mathrm{ml}$ distilled water and a solution temperature of $25{ }^{\circ} \mathrm{C}$ (Process $\mathrm{B}$, Table 2) was suitable for producing thin, compact, and uniform coating layers, as shown in Fig. 2. Without the boric acid, the grain size varied significantly, and tended to agglomerate into aggregates larger than $3 \sim 5 \mu \mathrm{m}$. Moreover, the surface could not be evenly covered when the thickness of the coating layer reached $10 \mu \mathrm{m}$ (Fig. 2a). A compact, uniform and thin coating was, however, obtained using Process B, as shown in Fig. 2b and 2c, under the same coating conditions. When both the boric acid level and solution temperature were increased (Process A), it was still possible to obtain a uniform and compact coating layer, but the grain size increased. This inevitably resulted in a much thicker coating ( $>4 \mu \mathrm{m})$, as shown in Fig. $2 \mathrm{~d}$. The surface roughness also increased from 29 to $46 \mathrm{~nm}$ with increasing amounts of boric acid.

\subsection{Influence of acid washing and neutralization treatment}

After mechanical polishing, it was necessary to wash the surface with $10 \mathrm{wt} \% \mathrm{HCl}$ solution in order to enhance the adhesion strength of the coating layer. Without this acid washing, the coating layer could be readily peeled off, even by blowing with compressed air. Figure 3 clearly shows the difference in surface roughness before and after acid washing and this sub-micron scale roughening of the surface by acid washing certainly contributed to much stronger adhesion of the coating layer to the surface. On the other hand, acid washing for too long produced a band of acid-affected sub-surface regions where delamination was prone to occur.

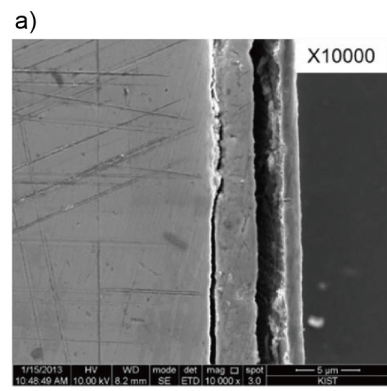

b)


c)
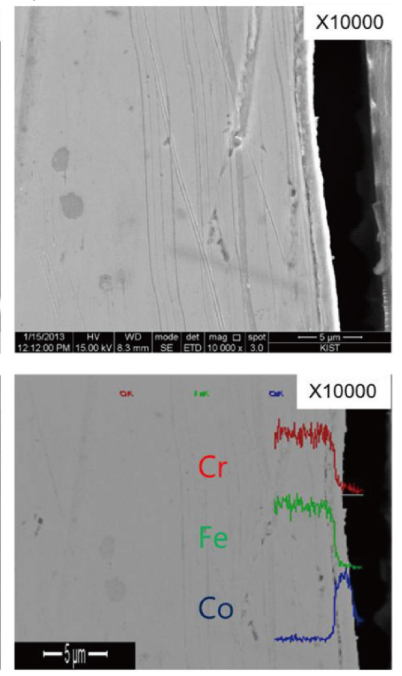

Fig. 4. Effect of acid washing time and neutralization treatment after acid washing on sub-surface delamination. a) 3 min acid washing, b) $3 \mathrm{~min}$ acid washing $+1 \mathrm{~min}$ neutralization, and c) $1 \mathrm{~min}$ acid washing $+1 \mathrm{~min}$ neutralization. Current density $=64 \mathrm{~mA} / \mathrm{cm}^{2}$, frequency $=100 \mathrm{~Hz}$, duty cycle $=80 \%$, total coating time $=40 \mathrm{~s}$. 

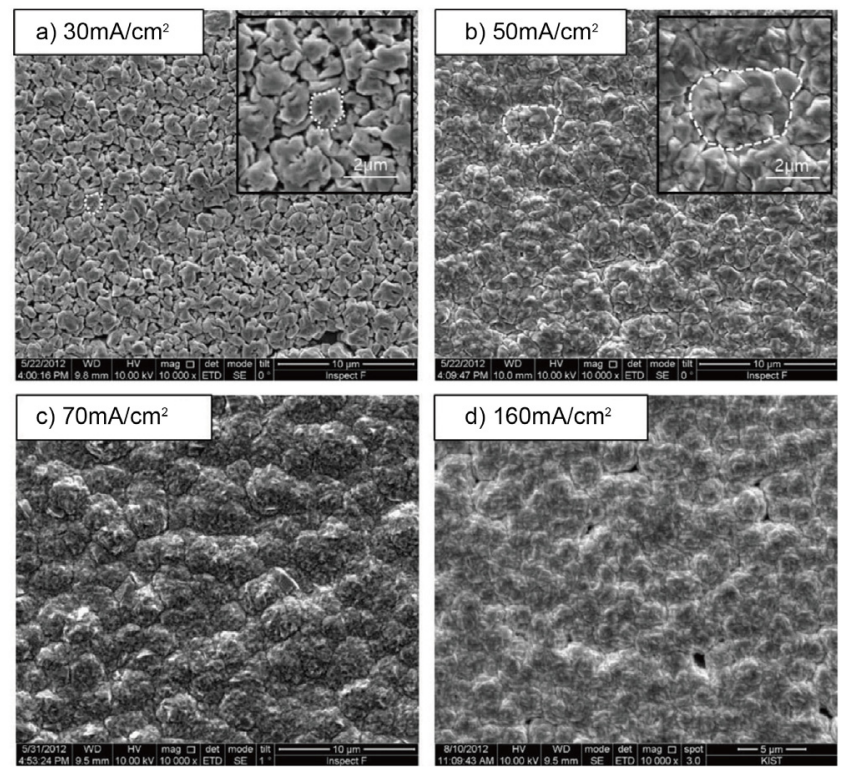

Fig. 5. Influence of current density on morphology of coating layer from solution without boric acid. Frequency $=10 \mathrm{~Hz}$, duty cycle $=50 \%$. Total coating time was a) $600 \mathrm{sec}$, b) $360 \mathrm{sec}$, and c) $240 \mathrm{sec}$, and d) $50 \mathrm{sec}$. The thickness of the coating layer is around $8 \mu \mathrm{m}$ for a), b), c) and $\sim 4 \mu \mathrm{m}$ for d). The insets in a) and b) illustrate the primary grain and the agglomerate, respectively. The primary grain and aggregate are marked by the dotted line in Fig. 5 a) and 5 b), respectively.

Figure $4 \mathrm{a}$ shows the cross section of the coated sample after acid washing for $3 \mathrm{~min}$. A clear line of cracks between the sub-surface region and the bulk, as well as the delamination of the coating layer from the substrate surface, can be observed. Neutralization treatment by $\mathrm{NaOH}$ solution after the acid washing significantly reduced the band width of the sub-surface region and suppressed both the interface and sub-surface cracks, but neutralization itself could not prevent these cracks completely (see Fig. 4b). By using a combination of reducing acid washing from 3 to $1 \mathrm{~min}$ and applying the neutralization treatment, it was possible to restrain the formation of the sub-surface region and cracks, as seen in Fig. 4c.

\subsection{Current density}

The average grain size of the coating layer deposited in the solution without boric acid decreased with increasing current density. A primary grain size of well below $1 \mu \mathrm{m}$ was obtained when the current density was above $70 \mathrm{~mA} / \mathrm{cm}^{2}$ (Fig. 5). Higher current density also promoted a more compact coating, mainly due to an increased tendency to form

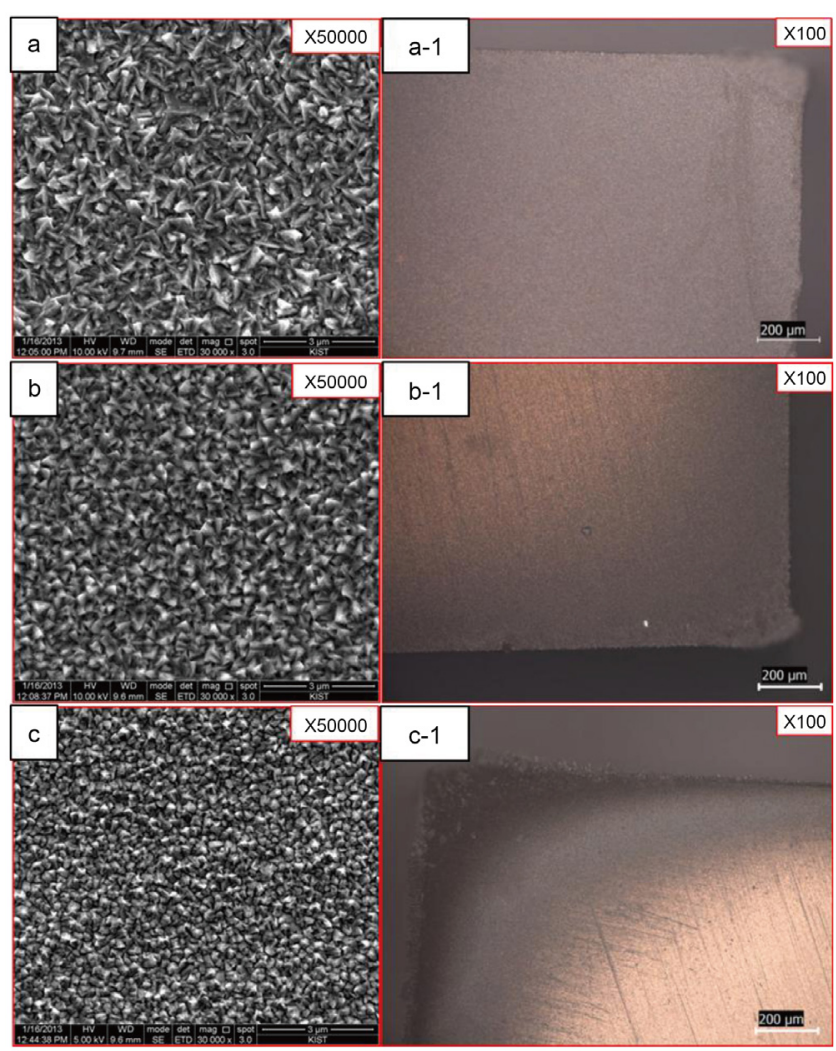

Fig. 6. Effect of current density on morphology and homogeneity of coating layer deposited under Process B condition. a) 64 $\mathrm{mA} / \mathrm{cm}^{2}$, b) $160 \mathrm{~mA} / \mathrm{cm}^{2}$, and c) $400 \mathrm{~mA} / \mathrm{cm}^{2} .100 \mathrm{~Hz} / 50 \%$, total coating time. a) $175 \mathrm{~s}$, b) $70 \mathrm{~s}$, and c) $28 \mathrm{~s}$.

more compact aggregates of fine primary grains (see Fig. $5 \mathrm{~b}$ and c). The thickness of the coating layer reached more than 8 $\mu \mathrm{m}$ under these coating conditions. When the current density was further increased to $160 \mathrm{~mA} / \mathrm{cm}^{2}$, it was possible to obtain a rather compact and thinner $(\sim 4 \mu \mathrm{m})$ coating even with less than half of the electrical charge density (current density multiplied by coating time) applied to the other three samples. It was observed, however, that too high current density resulted in a slightly larger primary grain size and lower filling density, with relatively large pores, as shown in Fig. 5d. In addition, the microstructure of the coating was not uniform and the surface became rough compared with those formed in the solution with boric acid.

When an appropriate amount of boric acid was added to the cobalt chloride solution, a much finer, compact and uniform coating layer could be prepared over a wide range of current densities, between 64 and $400 \mathrm{~mA} / \mathrm{cm}^{2}$ (see Fig. 6). It 




Fig. 7. Influence of pulse frequency on morphology of coating layer. The colored inserts are the 3D structures reconstructed by Mex 5.1 program. a) $10 \mathrm{~Hz} / 50 \%$ and b) $100 \mathrm{~Hz} / 50 \%$. Current density $=64 \mathrm{~mA} / \mathrm{cm}^{2}$, total coating time $=64 \mathrm{~s}$.

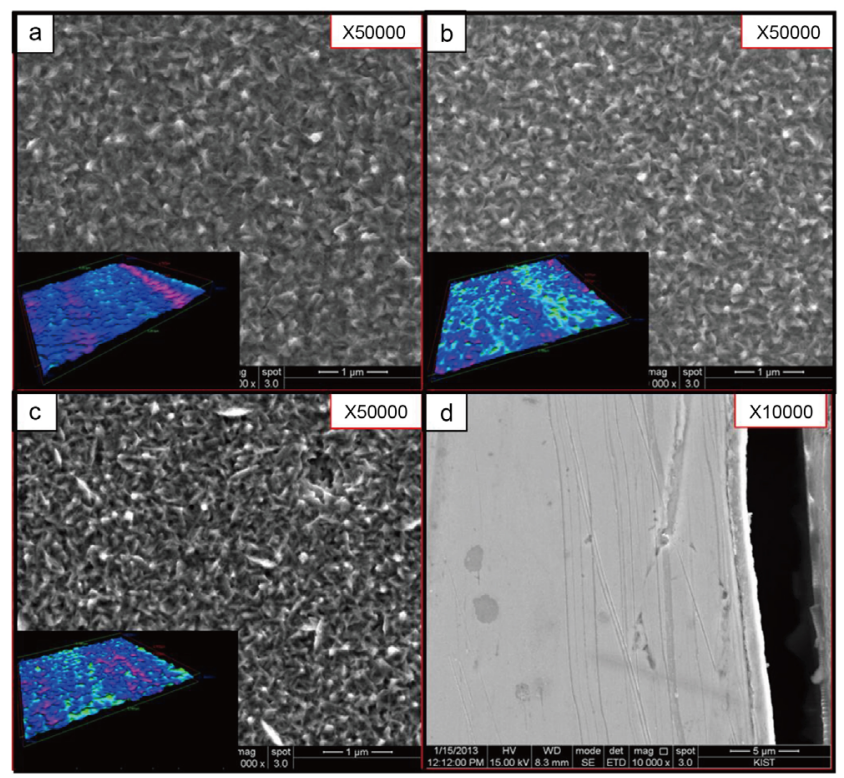

Fig. 8. Effect of duty cycle on morphology of coating layer. The colored inserts are the 3D structure reconstructed by Mex 5.1 program. a) $80 \%$, b) $50 \%$, c) $20 \%$, and d) cross section of the coating layer c). Frequency $=100 \mathrm{~Hz}$, current density $=64$ $\mathrm{mA} / \mathrm{cm}^{2}$, total coating time = a) $40 \mathrm{~s}$, b) $64 \mathrm{~s}$, and c) $160 \mathrm{~s}$. was also observed that the grain size decreased with increasing current density, but not as significantly as the case without boric acid. However, the so-called burnt deposit phenomena occurred at the corners of the sample when the current density was $160 \mathrm{~mA} / \mathrm{cm}^{2}$ even though the microstructure became finer and more regular (Fig. 6b). At a current density of $400 \mathrm{~mA} / \mathrm{cm}^{2}$, the area with over-burnt deposits at the corners increased significantly, while the morphology of the coating layer showed insignificant change, as presented in Fig. 6c. Nevertheless, the average thickness of the compact and uniform coating layer could be controlled to remain below $2 \mu \mathrm{m}$ under these coating conditions. This result clearly indicates that both the current density and the boric acid level should be carefully adjusted to prepare a thin, fine, compact and uniform coating layer in the Co chloride solution at room temperature.

\subsection{Pulse frequency and duty cycle}

Figure 7 shows the effect of the pulse frequency on the morphology of the coating layer under the Process B conditions. It seems that both the grain size and morphology of the coating layer looked almost the same, regardless of the square pulse frezuency. They were both compact and uniform and the thickness ranged from 1.5 to $2 \mu \mathrm{m}$. There was a slight improvement in surface roughness $(19 \mathrm{~nm})$ at $100 \mathrm{~Hz}$, compared with $27 \mathrm{~nm}$ at $10 \mathrm{~Hz}$, both with a duty cycle of $50 \%$, as shown in the colored inserts in Fig. 7. The influence of the duty cycle at $100 \mathrm{~Hz}$ on the morphology and surface roughness was also examined. The decrease in duty cycle tended to promote a more acicular microstructure and consequently rougher surface (see Fig. 8). When the duty
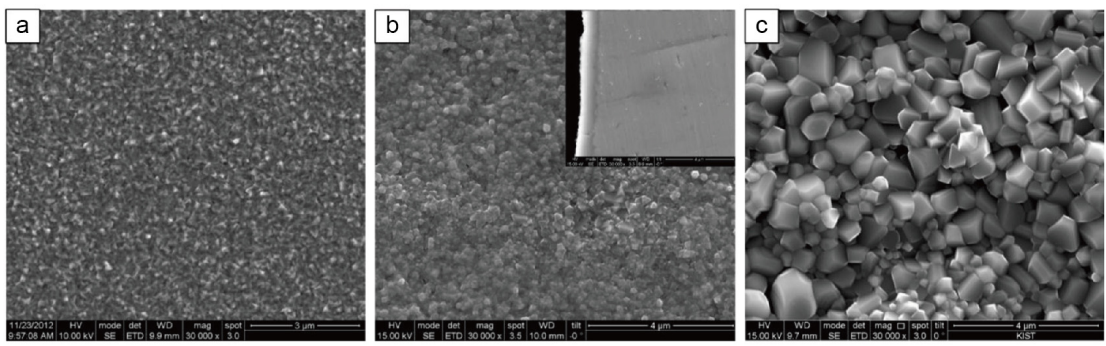

Fig. 9. Influence of oxidation heat treatment on microstructure of coating layer. a) as-deposited, b) after $1 \mathrm{~h}$ (the insert is a cross-sectional view), and c) after $100 \mathrm{~h}$. The coating condition is $64 \mathrm{~mA} / \mathrm{cm}^{2}, 100 \mathrm{~Hz} / 80 \%, 40 \mathrm{~s}$. 




Fig. 10. Change of chemical composition of coating layer with heat treatment time. a) as-deposited, b) after $1 \mathrm{~h}$, and c) after $100 \mathrm{~h}$.

cycle was $80 \%$, the roughness was $15 \mathrm{~nm}$, and it increased to $19 \mathrm{~nm}$ at $50 \%$. At $20 \%$, the microstructure became inhomogeneous and less compact with a wide range of pores. Moreover, a coating layer thickness in a range of 0.8 to $1.2 \mu$ $\mathrm{m}$ was obtained at $80 \%$ duty cycle, but it increased to more than $2 \mu \mathrm{m}$ at $20 \%$ even though the applied electrical charge density was the same. The reason why a higher duty cycle produced a thinner and smoother surface than a lower duty cycle was not clarified, yet it is believed to be related to the enhancement in the nucleation rate of the deposit during the on cycle, and the suppression of the grain growth during the off cycle time. This will naturally promote compact, uniform, and quick coverage of the surface and eventually produce a thinner coating layer. When the duty cycle becomes low, the growth rate seems to preferentially increase, mainly due to recrystallization during the off cycle [28].

\subsection{Post heat treatment effects}

Figure 9 presents the influence of the oxidation heat treatment at $800{ }^{\circ} \mathrm{C}$ in air. At a current density of $64 \mathrm{~mA} / \mathrm{cm}^{2}$ with $100 \mathrm{~Hz}$ and $80 \%$ duty cycle the grain size of the as-deposited coating was extremely fine $(<200 \mathrm{~nm})$ and uniform. The thickness of the coating layer is around $1 \mu \mathrm{m}$ and the surface roughness $15 \mathrm{~nm}$. After heat treatment for $1 \mathrm{~h}$, the grain size increased to $400 \mathrm{~nm}$ and the morphology of the grains changed from acicular to angular shape, but the grain size distribution seemed to remain relatively narrow.


Fig. 11. Phase composition change of coating layer. a) as-deposited and b) after $100 \mathrm{~h}$ heat treatment.

However, irregular grain growth was observed after $100 \mathrm{~h}$ and resulted in a wide range of grain size distribution varying from as small as $200 \mathrm{~nm}$ to a maximum of $1.5 \mu \mathrm{m}$. Although the oxidized coating layer did not look fully dense in the top view (Fig. 9c), the cross section observations confirmed that it was completely dense after only $1 \mathrm{~h}$ (insert in Fig. 9b).

The change in chemical composition of the coating layer was investigated by EDS analysis both from the top and the 


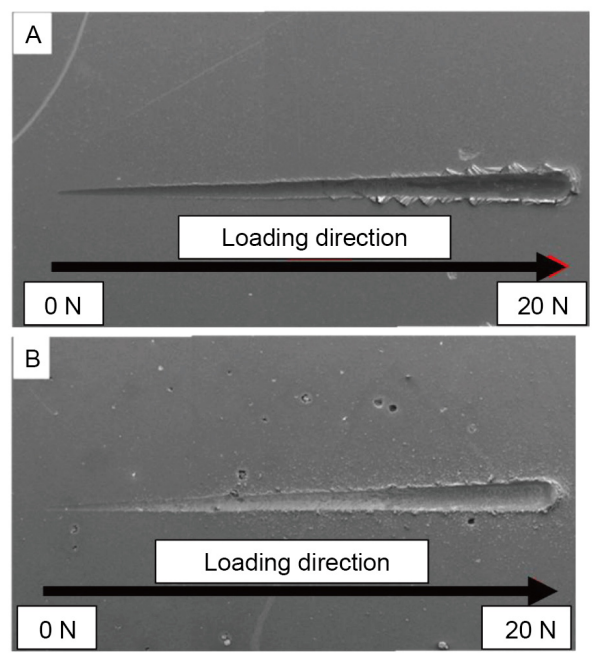

Fig. 12. Result of scratch test a) before and b) after $1 \mathrm{~h}$ heat treatment in air. The coating condition is same as the sample a) of Fig. 5.

cross-section views and the result is presented in Fig. 10. As expected, Co was the main element in the coating layer just after deposition. After $1 \mathrm{~h}$ of heat treatment in air at $800{ }^{\circ} \mathrm{C}$, the coating layer was oxidized and both $\mathrm{Cr}$ and $\mathrm{Mn}$ diffusion was observed while Fe diffusion was not significant. As shown in Fig. 10c, Mn clearly reached the surface of the oxidized coating layer, which points to a preferential diffusion of Mn compared to $\mathrm{Cr}$. The relative intensity of $\mathrm{Mn}$ $\mathrm{K} \alpha$ was significantly increased but those of $\mathrm{Co} \mathrm{K} \alpha, \mathrm{Fe} \mathrm{K} \alpha$, and $\mathrm{Cr} \mathrm{K} \alpha$ remained more or less the same.

The change in phase composition in the coating layer after $100 \mathrm{~h}$ of oxidation heat treatment in air is shown in Fig. 11. Prior to the heat treatment, only Co with a hexagonal structure was observed along with the substrate (bcc) peaks. A preferred orientation was observed in the analysis of the relative intensity ratio of the XRD peaks, which is common in the electrodeposition process [29,30]. After $100 \mathrm{~h}$ of heat treatment, at least three different types of complex oxides, including two spinel phases, $\mathrm{MnCo}_{2} \mathrm{O}_{4}$ and $\mathrm{CoCr}_{2} \mathrm{O}_{4}$, and a rhombohedral $\mathrm{Cr}_{2} \mathrm{O}_{3}$ phase, were detected. Based on the results of both the EDS and XRD analyses, it was deduced that the inner layer was rich in $\mathrm{Cr}_{2} \mathrm{O}_{3}$ and the outer layer was rich in $\mathrm{MnCo}_{2} \mathrm{O}_{4}$. It is also quite probable that the $\mathrm{CoCr}_{2} \mathrm{O}_{4}$ spinel exists mainly in the middle layer. It was therefore concluded that the diffusion of $\mathrm{Cr}$ to the surface can be quite effectively suppressed by applying a thin and uniform coating layer of $\mathrm{Co}$, which in turn will certainly reduce the volatilization of $\mathrm{Cr}[21,31]$.

Although the adhesion property of the coating layer could be significantly improved by adopting an appropriate acid washing and neutralization process, together with optimum coating parameters, the coating layer on the interconnect surface may not be strong enough to survive subsequent handling and assembling of the stacks. Very fortunately, it was found that a simple and relatively short heat treatment in air further improved the adhesion strength of the coating layer. Figure 12 shows the results of the scratch test. The applied load was increased gradually from 0 up to $20 \mathrm{~N}$. Without heat treatment, the coating layer started to peel off at around $10 \mathrm{~N}$, but it did not peel off even at $20 \mathrm{~N}$ after the oxidation heat treatment of only $1 \mathrm{~h}$ at $800{ }^{\circ} \mathrm{C}$ in air. Moreover, the thickness of the protective coating layer remained below $2 \mu \mathrm{m}$ even after $100 \mathrm{~h}$, so the growth rate seems to be rather slow, as described before.

From these results, it was concluded that a thin, fully dense, and uniform oxide layer, mainly composed of spinel phases, forms after a simple oxidation heat treatment in air, and the growth rate of this multi-phase oxide layer is very low. More characterization of the behavior of this protective oxide layer at high temperatures is on-going and will be published separately.

\section{CONCLUSIONS}

A thin and uniform cobalt layer was successfully coated on the surface of high $\mathrm{Cr}$ ferritic stainless steel (Crofer22 APU, Thyssen Krupp) by pulsed electrodeposition in an aqueous cobalt chloride solution with a reduced level of boric acid at room temperature. The thickness of the coating layer can be controlled to remain below $2 \mu \mathrm{m}$ while ensuring a fine, compact, uniform, and strongly adherent coating layer, by optimizing the boric acid level together with the surface treatment condition, as well as the coating parameters, including the current density, frequency and duty cycle of the square pulse. Post heat treatment in air was found to further improve the adhesion properties of the coating layer, and 
produced a coherent multi-component oxide layer which is believed to improve oxidation resistance and to reduce the $\mathrm{Cr}$ poisoning of the interconnect substrate for SOFC.

\section{ACKNOWLEDGEMENT}

This work was supported by the Convergence Agenda Program (CAP) of the Korea Research Council of Fundamental Science and Technology (CAP-11-05-KRISS).

\section{REFERENCES}

1. S. C. Singhal, Solid State Ion. 152-153, 405 (2002).

2. W. Z. Zhu and S. C. Deevi, Mater. Sci. Eng. A 348, 227 (2003).

3. S. P. S. Badwal, R. Deller, K. Foger, Y. Ramprakash, and J. P. Zhang, Solid State Ion. 99, 297 (1997).

4. K. Hilpert, W. J. Quadakkers, and L. Singheiser, Interconnects, Handbook of Fuel Cells, John Wiley \& Sons, Ltd (2010).

5. K. Hilpert, D. Das, M. Miller, D. H. Peck, and R. Weiß, J. Electrochem. Soc. 143, 3642 (1996).

6. Y. Matsuzaki and I. Yasuda, Solid State Ion. 132, 271 (2000).

7. S. P. Jiang, J .P. Zhang, and X. G. Zheng, J. Eur. Ceram. Soc. 22, 361 (2002).

8. N. Shaigan, W. Qu, D. G. Ivey and W. Chen, J. Power Sources 195, 1529 (2010).

9. P. Piccardo, P. Gannon, S. Chevalier, M. Viviani, A. Barbucci, G. Caboche, R. Amendola, and S. Fontana, Surf. Coat. Technol. 202, 1221 (2007).

10. S. Molin, B. Kusz, M. Gazda, and P. Jasinski, J. Solid State Electrochem. 13, 1695 (2008).

11. V. I. Gorokhovsky, P. E. Gannon, M. C. Deibert, R. J. Smith, A. Kayani, M. Kopczyk, D. VanVorous, Z. Yang, J. W. Stevenson, S. Visco, C. Jacobson, H. Kurokawa, and S. W. Sofie, J. Electrochem. Soc. 153, A1886 (2006).

12. P. E. Gannon, V. I. Gorokhovsky, M. C. Deibert, R. J. Smith, A. Kayani, P. T. White, S. Sofie, Z. Yang, D. McCready, S. Visco, C. Jacobson, and H. Kurokawa, Int. J. Hydrogen Energ. 32, 3672 (2007).
13. Y. Larring and T. Norby, J. Electrochem. Soc. 147, 3251 (2000).

14. H. W. Nie, T. L. Wen, and H. Y. Tu, Mater. Res. Bull. 38, 1531 (2003).

15. J. H. Kim, R. H. Song, and S. H. Hyun, Solid State Ion. 174, 185 (2004).

16. A. Balland, P. Gannon, M. Deibert, S. Chevalier, G. Caboche, and S. Fontana, Surf. Coat. Technol. 203, 3291 (2009).

17. Z. Yang, G. Xia, S. P. Simner, and J. W. Stevenson, J. Electrochem. Soc. 152, A1896 (2005).

18. Z. Yang, G. G. Xia, X. H. Li, and J. W. Stevenson, Int. J. Hydrogen Energ. 32, 3648 (2007).

19. X. Deng, P. Wei, M. R. Bateni, and A. Petric, J. Power Sources 160, 1225 (2006).

20. C. Collins, J. Lucas, T. L. Buchanan, M. Kopczyk, A. Kayani, P. E. Gannon, M. C. Deibert, R. J. Smith, D. S. Choi, and V. I. Gorokhovsky, Surf. Coat. Technol. 201, 4467 (2006).

21. M. Stanislowski, J. Froitzheim, L. Niewolak, W. J. Quadakkers, K. Hilpert, T. Markus, and L. Singheiser, J. Power Sources 164, 578 (2007).

22. Q. X. Fu, D. Sebold, F. Tietz, and H. P. Buchkremer, Solid State Ion. 192, 376 (2011).

23. J. Wu, C. D. Johnson, Y. Jiang, R. S. Gemmen, and X. Liu, Electrochim. Acta 54, 793 (2008).

24. J. E. Hong, T. H. Lim, S. B. Lee, Y. S. Yoo, R. H. Song, D. R. Shin, and D. Y. Lee, Trans. Korean Hydrog. New. Energy. Soc. 20, 455 (2009).

25. H. Ebrahimifar and M. Zandrahimi, Surf. Coat. Technol. 206, 75 (2011).

26. M. Paunovic and M. Schlesinger, Modern Electroplating, 4th Edition, 4 ed., John Wiley \& Sons, Inc., Richmond, TX, U.S.A. (2000).

27. J. H. Lindsay and H. J. Read, PLATING 57, 497 (1970).

28. J. C. Puippe and F. Leaman, Theory and Practice of Pulse Plating, American Electroplaters and Surface Finishers Society (1986).

29. E. Gómez, E. Pellicer, X. Alcobé, and E. Vallés, J. Solid State Electrochem. 8, 497 (2004).

30. N. A. Pangarov, Electrochim. Acta 7, 139 (1962).

31. J. Froitzheim, S. Canovic, M. Nikumaa, R. Sachitanand, L. G. Johansson, and J. E. Svensson, J. Power Sources 220, 217 (2012). 